THE

\title{
TRANSYLVANIA JOURNAL
}

\section{OF \\ MEDICINE}

AND THE ASSOCIATE SCIENCES.

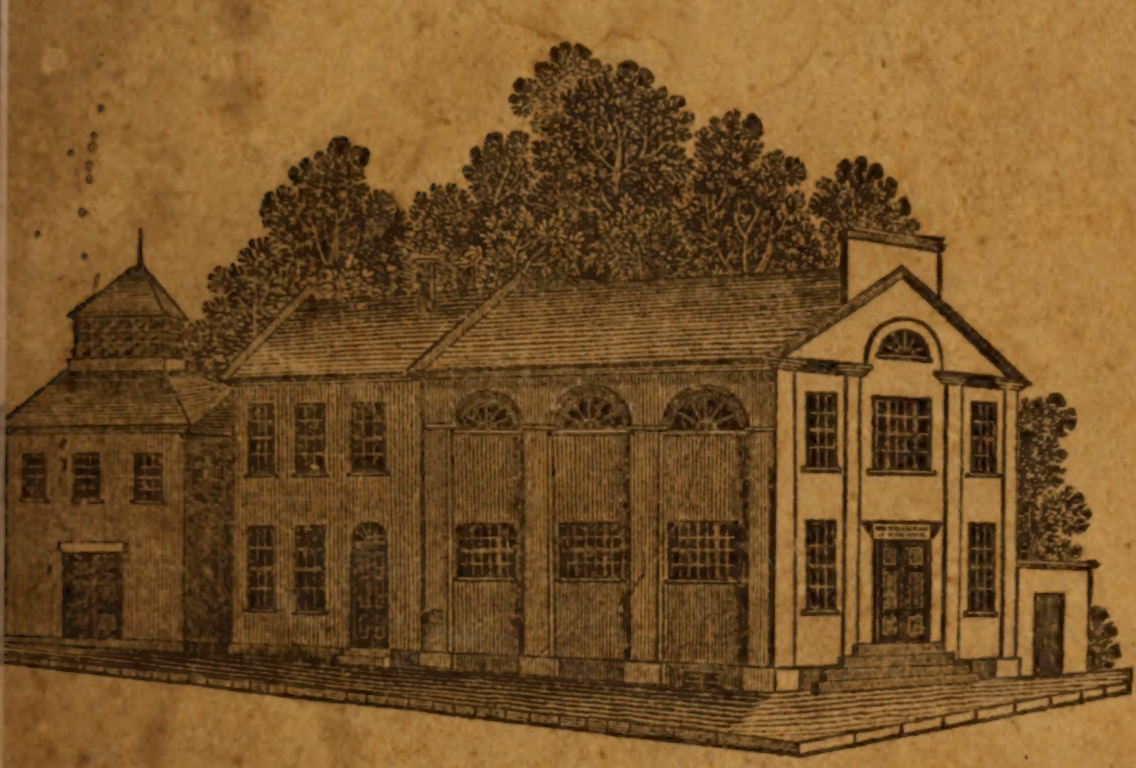

MEDCAX HALL OF TRANSYLVANIA UNIVERSTY, FOUNDED A. D. 1827.

VOL. I. NO. III.-AUGUST, 1828.

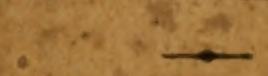

LEXINGTON, KEN.

PRINTEED BY J. G. NORIVOND,

"POOK $\triangle$ NDD JOB PESTER, AT THE "OLD HOTEL" SHORT BT. 



Arт. VI.-Florula Lexingtoniensis, sccundum florendi atatem digesta; or a descriptive Catalogue of the Phonogamous plants indigenous to this portion of Kentucky; arranged in the order of their periods of flowering. By Charles Wilkins Short, M. D. Professor of Materia Medica and Medical Botany in Transylvania University.

CONTANED FROM PAGE 265. No. 11.

FASCICULUS II.

For April.

23. Genvs. ACER L. Maple.

(Deriv. Latin; acer, sharp; pikes and lances having formerly been made of the wood.)

Class sth. OCTANDRIA-Order, MONOGYNIA.

Gen. Ch. Flozers mostly polygamous. Culyx about 5-cleft.

Petals 5, or none. Samaras 2, united at base, 1 seeded, winged.

Species 1st. Acer Saccharinum.

Sugar Maple.

Sp. Ch. Leaves palmately 5-lobed, subcordate at base, acu-

minate, glaucous beneath; peduncles corymbose, nodding.

Obs. The Sugar tree, as it is bere universally called, is one of the most common of our forest trees, and perhaps in this particular locality, it attains its greatest altitude. As it does not materially interfere with the growth of grasses beneath it, it is often reserved in clearing ground, particularly in situations intended for pasture or meadows. It here forms the densest. shade, and in autumn constitutes a prominent feature in the landscape, by the bright orange and red colours assumed by its leaves. Its wood is preferred to almost any other for fuel, and large quantities of sugar are annually made from the sap. Flowers about the first of April: seed ripen in midsummer.

Species 2d. Acer Negundo. Box Elder.

Sp. Ch. Leaves pinnate and tornate, unequally serrate; flowers dioicous.

voL. I. No, III. 
Obs. Not so common as the preceding, being more restricted to the borders of water courses. It is in every point of view less valuable than the Sugar tree, although the sap is occasionally procured in common with that of the former, in the making of sugar. Flowers at the same time.

Species $3 d$. Acer Dasycarpum.

White Maple. Sp. Ch. Leaves palmate, 5-lobed, acuminate, serrate, pubescent underneath, and almost white; flowers in clustered um. bels; germs tomentose.

Obs. This tree, which in its general habit resembles the Sugar Maple, is however easily distinguished from it by the lighter and smoother colour of the bark, and the singular downy whiteness of the leaves. It attains as large a size and is valuable as fuel and for some of the mechanic arts. Sugar is also made from its sap, but it is now rarcly met with in this neighbourhood.

24. Granus. VERONICA. L. Speedwell. (Deriv. Prolsably a corruption of Vetonica, or Betonica, Betony.) Class 2d. DIANDRIA-Order, MONOGYNIA.

Gen. Ch. Calyx 4-parted. Corolla rotate, 4-lobed, unequal, the lower segment narrower. Capsule 2-celled, obcordate; seeds few.

Species 1st. Veronica Perigrina.

Neckweed.

Sp. Ch. Flowers solitary sessile; leaves oblong, rather obtuse, toothed and entire; stem erect.

Obs. Stem erect or partially procumbent, round, smooth, frequently without branches, 8 inches high. The lowest leaves opposite, sparsely toothed; the upper alternate, linear-lanceolate, nearly entire. Flowers axillary, solitary, nearly sessile. Corolla small, white and, like both the following, very caducous. Capsule inversely heart-shaped and larger than either of the succeeding species.-The plant has had some reputation in scrofula, hence the name of Neckweed. Flowers middle of March and after. Abundant in gardens and cultivated fields.

Species 2d. Veronica Serpyllifolia.

Speedwell. Sp. Ch. Raceme terminal, somewhat spiked; leaves ovate glabrous, crenate.

Obs. A small plant common in grass lots, and scarcely distinguishable except when in bloom; stem decumbent, putting forth radicles; lower leaves roundish, ovate, smooth; flowers sky- 
blue with darker stripes, larger than in the preceding species, and borne on the summit of the stem: whole plant does not exceed 6 inches in height, frequently less. Flowers from 1st of April to the last of that month, and occasionally throughout the season.

Species 3d. Veronica Agrestis.

Germander.

Sp. Ch. Flowers solitary, and with the cordate leaves nearly sessile; stem rough, hairy.

Obs. This species is readily distinguished from either of the preceding by its more hispid appearance, and its more diffused and branching habit. The flower is also smaller and of a deeper blue than the preceding. The leaves are mostly opposite, cordate, ovate, notched, strongly veined particularly on the lower surface, and very pubescent. Cultivated fields and pastures common: flowering rather later than the last, 5th-10th of April.

\section{Genus. CARPINUS. L.}

(Deriv. Celtic, Car, wood, and pin, head; i. e. wood suitable for making yokes for cattle. De Theis by Darl.)

Class 21st. MONOECIA.-Oraer. POLYANDRIA.

Gen. Ch. Masc. Scales of the calyx ciliated. Stamina about 10. Fex. Calyx scales 2-flowered. Corolla trifid. Nut ovate, sulcate.

Species 1st. Carpinus Amrricana.

Iron-zood. Sp. Ch. Leaves oblong-ovate, acuminate, unequally serrate; strcbile with 3-parted scales, the middle segment oblique, toothed on one side.

Obs. The Iron-wood, by which name this tree is here always called, is so well known as to require no description. In other portions of the union it is called Hornbeam. It is found throughout this state among other forest trees and is perhaps especially abundant in the country about Lexington, growing generally to the height of 30 or 40 feet.--The wood is possessed of great hardness and strengtb, but is not applied to many nseful purposes. Flowers beginning of April.

Sym. C. Caroliniana. Walt.

$$
\text { 26. Genus OSTRYA. Micheli. }
$$

(Deriv. Ostreon. Greek, a shell or scale; from the resemblance of its capsules. De Theis.) 


\section{Class 21st. MONOEClA. Order, POLYANDRIA.}

Gen. Ch. Ament imbricated. Masc. Calyx consisting of scales. Filament of the stamina ramose, Fen. Ament naked. Capsules inflated, imbricated at the base, 1 -seeded.

Species 1st. Ostriya Virginica. Hop-hornbeam.

Sp. Ch. Leaves ovate-oblong, cordate at the base, acuminate, unequally serrate; strobile oblong-ovate, erect? buds acute.

Obs. This small tree which is also called Ironwood in the Northern and Eastern States, is readily distinguished from the former by its somewhat shaggy bark and differently formed strobiles, or seed vessels: these in the present tree being so similar to those of the garden hop as to have given it the appropriate name of Hop-hornbeam. It is likewise frequent in this locality being found in company with the preceding. Its wood is also hard and strong; but the size of the tree being inconsiderable, it is susceptible of no very useful application. Flowers about the 1st of April.

Syn. Carpinus Ostrya Mich.

\section{Genus. PULMONARIA. I.}

(Deriv. Pulmones the lungs, from its former reputation in diseases of these organs.)

Class 5th. PENTANDRIA. Order, MONOGYNIA.

Gen. Ch. Calyx prismatic 5-angled, 5-toothed: Corolla funnel-formed, border 5 -lobed; throat pervious.

Species 1st. Pulmonaria Virginica. American Cozuslip.

Sp. Ch. Smooth; slem erect; calyx much shorter than the tube of the corolla; radical leaves ob-orate, oblong, obtuse; stem leaves narrower.

Obs. This very showy plant, so common in most parts of the Union, is comparatively rare in this immediate vicinity, being only occasionally met with on the alluvion banks of Elkhorn and Kentucky river. Stem 12-15 inches high with numerous broad, smooth, spathulate leaves issuing from the root, and becoming narrower on the stem. Flowers numerous in a terminal, pendulous raceme; their colour varying from pale rose, through violet to blue. April 1st to 15th. 


\section{Genus. DELPHINIUM. I.}

(Deriv. Delphinion of the ancient Greeks, from some fancied resemblance of its nectary, to the Dolphin. Smith.)

\section{Class 12th. POLYANDRIA-Order, TRIGYNIA.}

Gen. Ch. Calyx none. Petals 5. Nectarium 2-cleft, base extending into a hollow spur. Capsules $1-3$.

Species 1st. Denphinium Triconne.

Wild Larkspur.

Sp. Ch. Cautis simple. Leaves 5-parted many-cleft with

the segments linear; raceme straight; nectary shorter than the corolla; capsules 3 , arched, expanding from the base.

Obs. The striking similarity of this plant, to the common Larkspur of the gardens at once points it out to the novice. Stem hollow, large at the base, tapering quickly to a point at the summit; rarely more than a foot high. Flowers varying in colour from dark blue to light blue, purple pink and white, are succeeded by three, horn-shaped capsules, whence the specific name. Found on creek sides, particularly preferring rocky precipices. 1st to the 10th of April.

This is one of the plants which are indefinitely called staggerweed; to eating which the diseases of cattle are sometimes attributed.

\section{GenUs. SEDUM. L.}

(Deriv. Latin Sedere to sit, from its growing or sitting on the surface of rocks.)

Class 10th. DECANDRIA-Order, PENTAGYNIA.

Gen. Ch. Calyx 5-cleft. Petals 5. Capsules 5, superior, many seeded, opening internally.

Species 1st. Sedum Ternatum.

Stone-crop.

Sp. Ch. Creeping; leaves flat, round spathulate, by threes; cyme generally 3-spiked; flozbers white.

Obs. This handsome little vegetable is apt to mislead beginners in the study of plants, from the circumstance of many of the flowers being octandrous, and the calyx, petals and germs being arranged by $4 \mathrm{~s}$ instead of $5 \mathrm{~s}$ as laid down in the generic character. The most of the species of this genus, however, are strictly decandrous, and indeed the central flower of the present species is so always. Root perennial; stem procumbent;-lower leaves orbicular; upper lanceolate; all thick and 
succulent. On the shelving rocks bordering Elkhorn. FIowers beginning of April.

Syn. Sedum Portulacoides, Muhl.

Species 2d. Sedum Pulchellum.

Sp. Ch. Glabrous, stems assurgent; leaves linear, succulent; obtuse; cyme many-spiked; flowerssessile.

Obs. Mainly differing from the preceding in the leaves which are linear and cylindrical. Found in company with it on moist rocks and sometimes on the trunks of decaying trees. Owing to this circumstance it is frequently mistaken for a moss by those unacquainted with its character. Flowers a little after the former.

\section{Genus. \\ VIOLA. \\ L. \\ Violet.}

(Deriv. A Latin name of obscure Greek derivation.)

Class 5th. PENTANDRIA-Order, MONOGYNTA.

Gen. Ch. Calyx 5-leaved, produced at the base. Corolla 5petalled, irregular, the lower petal cornute behind. Anthers cohering: Capsule superior 3-valved, 1 celled.

Species 1st. Viola Cucullata.

Hooded Violet.

Sp. Ch. Stemless; leaves cordate, somewhat acute, glabrous, hooded at base; flowers inverted; petals obliquely bent.

Obs. This is with us the most abundant of the violets, as well as the first to bloom; the whole surface of moist meadows and pastures being covered with them in the fore part of April.Petals blue and purple, white at base; the base of upper one with violet-coloured veins; of the two lateral bearded; of the lower smooth. Peduncles longer than the leaves with the sum. mit reflexed. Stipules linear--1st to 15 th April.

Syn. Viola cordata. Walt.

Species 2d. Vrola Obliqua. Aiton. Sp. Ch. Stemless; smooth; leaves cordate, acute, flat, crenate, serrate; flowers obliquely bent; lateral petals bearded; inferior ones acute, carinate; siipules lanceolate.

Obs. This species is by no means easily distinguished from the preceding, with which it is found in common. It is, however, a larger plant, and minute examination will detect specific differences in the leaves, petioles, stipules and flowers. (See 
Schwrinitz: monograph on the genus Violat in American Journal of scieure and drt., Vol. 5, No. 1.)

Species 3d. Vioza Ochroléuca? Schw.

White Violet.

Sp. Ch. Cauleseent. Stem somewhat erect, branched, pur-

plish, mooth: leares cordite, acuminate; stipules oblonglanccolate, dentate-ciliate.

Ob. The present species, about which there scems some obscurity in t! hooks to which 1 have referred, is easily recogrnized from is congeners of this locality, by its large, white flowers, with a tinge of yellow. It is found in common with the two precedinge and forms dense patches among the grass in moist situations. As the smason advances it rives with a slender flexume st:m to the height of $8-12$ inches, and then produces inconspicuous, apetalous flowers.

Syn. V. Striata. Wild. Pers. Pursh. Nutt.

Sppcies 4th. Viola Hastata.

Yellow Violet.

Sp. Ch. Caulescent smooth; stem simple, leafy ahove; leures hastate, on very long petiules; stipules minute, ciliate denticulate.

Obs. This, althongh much less frequeritly met with than either of the preceding, is casily distinguished from themby the deep yellow colour of its flowers. Rare in this neighbourhood, being only orcasionally found in shaded woods. Flowers during the fore part of April.

Speries 5th. Viola Concolor.

Muhl.

Sp. Ch. Caulescent. Stem straight erect; leares cuneatelanceolate; stipules lanceolate entire; peduncles very short, axillary, 2-3 llowercd; petals comivent, emarginate: spur none.

Obs. This anomalous species, which appors to me very unnaturally grouped with the violets, is also very rare in this section of Kentucky. I have only met with it in a solitary, secluded, rocky spot lying to the left of, and near the Woodford roat. Several stems issuing from a single root, arise erect and unbranched to the height of 1 or 2 feet, hearing lance-shaped. pointed leaves. The flowers are small and greenish-coloured, produced in $2 s$ and $3 s$ at the axills of the upper leaves about the 10th of April. The whole habit of the plant, however, is so unlike that of the genus, as casily to mislead the student. 
Other species of this extensive tribe are no doubt to be found in the neighbourhood of Lexington: as yet however I have detected only the above. In other parts of the state six or eight additional species have been met with.

31. Gevus. LEONTODON. L. Dandelion.

(Deriv. Greek Leon a lion and odous a tooth; from a fancied resemblance in the teeth of the leaves.)

Class 19th. SYNGENESIA-Order, AQUALIS.

Gen. Ch. Calyx oblong, double; outer one loose. Receptacle naked; pappus feathered.

\section{Species 1st. Leontodon Taraxacum.}

Sp. Ch. Outer scales of the calyx reflexed; scapes 1 -flowered; laves runcinate.

Obs. No portion of the Union is more completely overrun by this naturalized foreigner than this section, being so abundant as to give a yellowish hue to pastures in early spring (1st of April) from the profusion of its flowers.

(Specific name derived from the Greek tarasso to move, or trouble, from its reputed diuretic and laxative properties.)

\section{Genus. POLEMONIUM. L}

(Deriv. According to Pliny derived from Greek, Polemos, war: because Kings had contended for the honor of its discovery.)

Class 5th. PENTANDRIA-Order, MONOGYNIA.

Gen. Ch. Calyx 5-cleft. Corolla somewhat rotate, 5-lobed, tube short, closed at its base by 5 staminiferous valves or scales. Stigma trifid. Capsule 3-celled, superior.

Species 1st. Polemonium Reptans. Jacob's-ladder. Sp. Ch. Leazes piunate, generally by sevens: flowers terminal nodding.

Obs. This beautiful native well deserves a place in all flower-gardens; it bcars transplantation well and improves by cultivation. It is a hardy plant and, with a little protection, may be made to bloom throughout the winter. Its favorite localitics are in rich shaded situations among rocks and decaying logs, where its spikes of sky-blue flowers, with white anthers, appear about the 19th of April. There is a variety with white flowers. 


\section{Gexts. PHIOX. L. Mild Pinl:}

(Deriv. Gresk Phlox, fire or flame, in allusion to the colour of the flowers.)

Class sth. PE.VTANDRIA-Order, MONOGY.1.

Gen. Ch. Calyx deeply 5-rleft, segments connivent. Corolla salver-formed; border 5-lobed, flat; tube more or less curved. Staminu unequal. Capsule subrotund, 3-celled; cells 1-seeded. Species 1st. Phiox Divaricata? Sizrę William. Sp. Ch. Stem low, pubescent, decumbent; leaves oval-lanceolate; branches divaricate, loose, few flowered; segments of the corolla obcordate, teeth of the calyx subulate linear. Tor.

Obs. Of this numerous genus, there are but few natives of shis locality. The present species is easily distinguished from others, by its earlier period of flowering, its lower growth, rarely rising above 1 foot, and by its partially decumbent habit. The leaves, in the specimenis I have met with, have been universally opposite, sessile, and few in number. Flowers in a terminal panicle. pale blue or more frequently rose-coloured. Generally known under the name of Sweet William or May Pink. Abundant in half reclaimed lands and borders of fields, from 10th to 20th April.

\section{Genes. CFRASTIUM. L.}

(Derir. Greek licration, a little hom, in allusion to the shape of the capsule. $S m$.)

Class 10th. DEC.1NDRI.A-Order, PENT.AGY.\%.

Gen. Ch. Calyx 5-leaved. Petals 5, bifid or emarginate. Capsule 1-celled, bursting at the summit with 10 teeth.

Species 1st. Cerastium Hirsutum.

Monse-ear Chickiveal.

$S p . C h$. Very hairy, diffuse; learcs oval obtuse, counate; flozers clustered; petals 2-cleft at litlle longer than the acute calyx. Ell.

Ols. Mr. Elliott's description suits this plant remarkably Stems rarely rising roore than $6-8$ inches from the ground. Flowers inconspicuous, rarely fully expanded, small, white. Common in cultivated ground in grass lanid frequently assuming a jellowish colour. Flowers middle of $A_{\text {p ril. }}$ 


\section{Species 2d. Cerastium Longe-pedunculatum.}

Sp.Ch. Viscid-pubescent; leaves oblong-tinear, acute; perliencles long.

Obs. Altogether a larger plant than the preceding, rising sometimes to the height of 12 inches, but more frequeitly semiprocimbent. The whole plant is remarkably viscid to the touch, and is strongly characterized by the circumstance which affords the specific name, viz. the unusual length of the peduncles. Foand in common with the former but much more rare. Flowers a few days later.

Syn. C. Glutinosum. Nutt. C. Nutans. Torrey.

35. Genus. ERIGERON.

Fleabane.

(Deriv. Creek Er, tho spring, and geron, an old man; because it is hoary in the spring. $\mathbf{S} m$.)

Class 19ih. SYNGENESIA-Order, SUPERFLUA.

Gen. Ch. Calyx imbricate. Florets of the ray linear, very numerous. Pappus double; extcrior minute; interior hairy, of few rays. Receptacle naked.

Species 1st. Erigeron Bellidifolium.

S.. Ch. Hairy, graj, ratical lences obovate, spathulate, subserrate: stem lerves remote, oblong-ovate, amplexicaul, entire; stems 3-5-flowered; rays nearly twice as long as the hemispherical calyx. Torrey.

Obs. The present species, as it occurs in this vicinity, differs from the forcgoing description in having the lower stem-leaves coarsely though irregulariy toothed, while the upper ones only are entire or untoothed. The number of flowers also exceed that mentioned in the specine description, being often as num rous as $8-10$. "The lower's begin to shew themselves abeut the 19th of April, when the plant is only 3-4 inches high, and continue unfolding, wntil it has attained the height of 18 or 24 inches. The central flower, ats observed by Mr. Elliott, is generally larger than the lateral ones-their colour varying from delicate pink to white-in pastures and moadows abundant.

\section{Species 2d. Erigeron Philadelphicum.}

Sp. Ch. Pubescent; lentes cuncate-oblong, cauline semi-anplexicaul; rays capillary. 


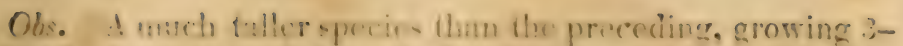

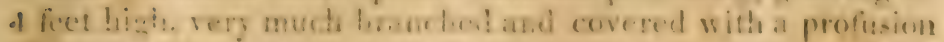
of -mall white or pale purple flowers, with yellow diske. 'This

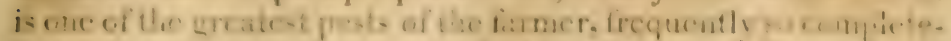

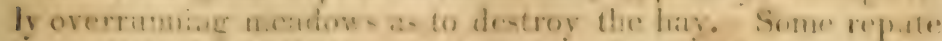

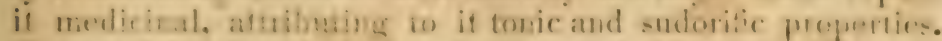
Flowers hater than dere has, and contimes in bloom much longer.

$$
\text { 36. Graves. PIACELIA. Jussieu. }
$$

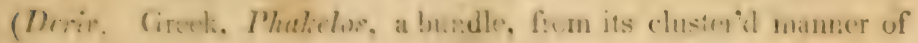
flowering.)

Class 5th. PEVT.1.1PRII-Crider, MO.10G Y'XA.

Gan. Ch. Cilyz j-defl. Comlliz 5-cheti. Stumens exerted. Cupsesle 2-celled, 2-valved, 4-secded. Ell.

Sprcies 1sto Phacela Furbriata.

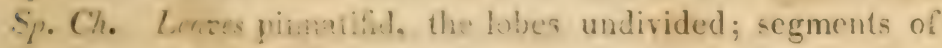

the corolla fimbriate. Ell.

Obs. This plant, abundant throushout the western country, has at fir-t glance the aspect ard mode of fowering of an ligdruphlilam. 'The whoie part is hi-pid, the lower fraves sone' what petioled, the upper sesile or anplexicaul; all altermate and pinnatitil. Flowers of a pale blue are borne in a simple terminal raceme, rovelute before fow erier. become erect aftermards. (alyx persi-tiat. Strle 2-cleft. Grows inclumps; onter hratehes seni-prostrate; central more erect, tising to the h.ieht of 10-12 iaches. Moist meadows-lowers from the middle of April.

37. Geves. CERCIS. L.

(Deriv. Greek kerkis of Theophrastus.)

Class 10\%. JEC:4.1\%PI.4-Order. MONOGYN.4.

Gin. Ch. Calyx 5-tonthed, gribbous at hase. Corolla papilionaceous, with a short vexillum under the wings. Sted ressel a legume.

Species 1st. Cercis Canadensis. Red. Burl.

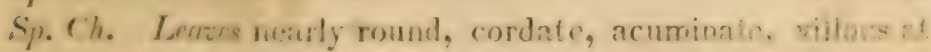
the axile of the nerves, legmmes on short font-stalls.

Ol,s. The Rent-bed, by which name it is ulversali. honow"

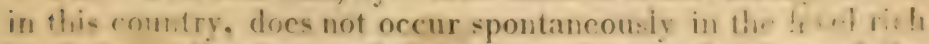
lands immediately ronud Iexington; but is the lites of the 
country becomes more broken on approaching the Kentucky river, it is met with in great abundance; constituting, by the profusion of its pale rose-colour'd flowers, a plcasing object in early spring, before any of the forest trees have put forth their leaves. It never rises, even in the best soil, to any considerable elevation, but when growing singly its branches extend horizontally to a great extent in proportion to its height. The flowers appear generally by the 12 th of April and are succeeded by a great number of pods, borne on short peduncles; and the tree becomes clothed, towards the 1 st of May, with large heart-shaped leaves of a rich dark green.
33. Gevus.
FRAXINUS.
L.
Ash Tree.

(Derix. The Latin name of the Ash Tree: Etymology obscure. Darl.)

\section{Class 2d. DECANDRIA-Order, MONOGYNTA.}

Gen. Ch. Polygamous: Calyx none, or 4-parted. Corolla none, or 4-petalled. Samara 1-seeded: wing lanceolate.

Species 1st. Fraxinus Aurricana.

White Ash.

Sp. Ch. Leaflets petiolate, oval-lanceolate, acuminate, slightly

toothed, glaucous beneath.

Obs. This is one of the largest as well as the most useful of our forest trees; growing frequently to the height of 80 feet with a diameter of 3 feet; and applicable to many useful purposes in building, the mechanic arts and rural economy. It is readily distinguished from the Blue.Ash, with which it is found in common, by its whiter, ash-coloured bark. Flowers about the middle of April, and is abundantly met with on the richer lands throughout the state.

Syn. F. Discolor, Muhl. F. Alba. Marshall. F. Acuminata. Pursh.

Species 2d. Fraxinus Quadratgulita.

Blue Ash.

Sp. Ch. Leaflets subsessile, oval-lanceolate, serrate, pubescent underneath: younger branches quadrangular.

Obs. The blue ash is more limited in its geographical range than the preceding species; but in this locality it is equally abundant and attains nearly if not quite to as large a size. Its wood unites strength with durability and elasticity and hence is applicable to a great variety of uses. Flowers about the same time with the former.

Species 3d. Fraxinus Sambucifolia.

Black Ash. 
Sp. Ch. Iacflits sessile, oval-lanceolate, serrate, acuminate, base rounded and unequal.

Obs. This is also a large tree, but muchless frequent thail either of the preceding, in this neighbourhood; in the ne-torn part of the State, on the contrary, it becomes more ahundant than either, and is made to supply the purposes of henti. Its wond, however, being marked with hlack streaks makes it more unfit for flooring. It is said, moreover, to be less durable than the: two species just mentioned.
39. Genus.
LAURUS.
L.

(Derir. The ancient Latin name of the Bay tree: Origin obscure. Darl.)

Class 9h. E.N:VE.1NDRI.1-Order, MO.vOGYXI.

Gin. Ch. Calyx none. Corolla resembling a calyx, 4-6 parted. Nectary with 3 two-awned glands surrounding the germ.

Stamina variable, 3 to 14 . Drupe 1 -seeded.

Species 1st. Laubus Benzoin.

Spicezood.

Sp. Ch. Leares obovate, lanceolate, pubescent underneath: flowers in clustered umbels: buds and pedicels smooth.

Obs. The Spicewood is a common shrub throughout the Union; and is here met with in all shaded, rich woods where the undergrowth has not been destroyed; preferring mostly situations near small streams of water. Its little, yellow, clustered flowers appear towards the middle of April or earlier, before any appearance of foliage is observed on the branches, and are succeeded by numerous bright red berries. The bark of the wood is pleasintly aromatic and is sometimes used in warm infusion as a diaphoretic.

Species $2 d$. Lacrus Sassafras.

Sassafras.

Sp. Ch. Mostly dioicous; lrazes some oral and entire, others 2 or 3 lobed.

Obs. This tree, although very abundant in some portions of the state, is not met with any where within a few miles of Lexington. On approaching the Kentucky river, within the bounds of the county of Fayette, it is seen growing in fence corners, having sprung up since the clearing of the land: and on the alluvions and hills bordering that river large trees of 12-18 inches diameter are frequently seun. Flowers generally towards the middle of April. in somewhat the same manner with 
the Spiecwood: its frut lowever is larger and of a blue colour. Popular opinion has long since attributed much virtue to tho bark of the Sassaffas root; and medical cotmenance is frequently given to the idea of its heing a purifier of the bleor.

By some hotanists these two species of Laurus are thrown into a sub-genus called Euosmus, from their pleasant aroma.

40. Graes PHILANGIUM. Tuinefort. Wild Hyacinth.

(Brriv. A Greek name of a plant, mentioned by Dioscorides, des rived perhaps fiom phalagx, a phalanx or legion, in allusion to the number and disposition of its flowers.)

Class 6th. HEXANDRIA-Order, MONOGYNTA.

Gen. Ch. Curolla of six petals, spreadiug. Filaments naked or smooth. Capsule ovate. Seeds angular.

Species 1st. Phalangium Esculentum.

Nuttall.

Sp. Ch. Root bulbous, leares all radical, linear, carinate; stigma minutely 3-cleft.

Obs. This is decidedly one of the most beautiful of our indigenous plants; throwing up from the centre of a tuft of smooth grass-like leares, a long solitary stem 1 to 2 feet high, sheathed below by a few convoluted bractes, and clothed at the summit by a number of large purple or palc-blue flowers, 10 or 12 of which are in perfection at a time; these slowly shrivelling. (marrescent,) others are crolved, so as to keep up a succession of bloom for several days. The root, which is bulbous and situated deep in the ground, is eatable and rutritious-Frequent in moist meadows in certain localities, but generally disappearing upon culture-Flowers from the 20th of April.

Syn. Scilla Esculenta. Bot. Mag. Phalangium Quamash. Pursh.

\section{Genus. ASARUM. I.}

(Deriv. The Latin name of a plant, spoken of by Pliny.)

Class 11th. DODECANDRI.9-Order, MONOGYNIA.

Gicn. Ch. Calyx 3-4 cleft, supcrior, persistent. Corolla none. Anthers adhering to the sides of the filaments. Capsule 6-celled.

Species 1st. Agarum Canadense. Wild Ginger.

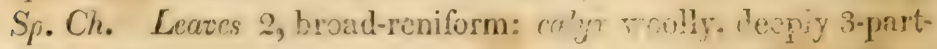
ed, reflexed. 
OM.s. Tho witd einger is readily detectod, by its two large

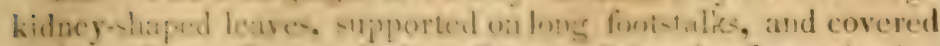
with a velsen solimes, - by it solitary and singular flower issuing from the asing theteo leases; and hy the aromatir. odour of

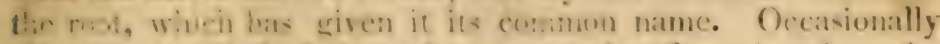

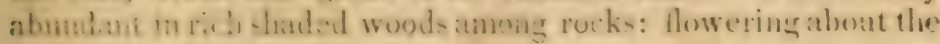
20th of April.

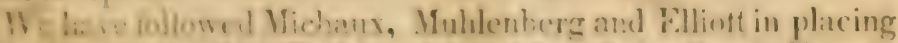
thio pient indie ef ... Dedecardria, although by Pur-h, Nuttall, Burron and formes it is ranhed uider Gyandrial; and by Darlington in Pulyandria.

Syn. A. Carolinianum. Walt.
42. Gesus.
CAULOPHYLLUM.
$M x$.

(1)erir. Greek Koulos, a stem and phyllon, a leaf: frem the re scmblance of the stem to a leaf-stalk. Michaux.)

Class 6th. MEXYIIDRT.I-Orha, MONOGYA\%.

Gen. Ch. Culye 3-6 leaved. Corolln G-petalled, with a sub. reniform nectary on cach claw. Berry stipitate, 1 -seeded.

Species 1s\%. Callophylica Thalicthomes. Papponse-root. Sp. Ch. Glubrous; lecers supradecompound; leaflets oval, terminal one 3-lobed.

Obs. Thit, the only species of the cenis, wa- one alundant throughou this country, bat has now almos disippeared from the more cultivated districts, and is coneequently rare about Lexington, heing only met with in the more secluded and unfre prented woodlands. It grows to the height of 12 or 18 incher, produring a single triternate compounded leaf; and a panicle of small greenish-yellow flowers, succeded by dark-blue berries which are covered with a mealy powder.

Under the name of Pappouse-ruot this plant has had some medical virtnes a-cribed to it.-Flowers towards the latter part of A pril: berrics ripe in June.

Syn. Leontice Thalictroides. Willd.
43. Genus. 无SCULUS.
L.

(Derim. Latin Escr. food: the fruit of some of the species being esculent.)

Clnss 7h. HEPT.1.VDRI.I-Order, MOVOGY.V\%.

Gex. Ch. Calyg 1-leaved, 4-5 toothed, ventricoss. Curolle 
4-5 petalled. Pctals unequal inserted upon the calyx. Cupsule 3-celled. Seeds large, solitary.

Species 1st. Esculus Pallida.

Common Buckrye. Sp. Ch. Leafets by 5s: corolla 4-petalled: stamina mostly 7, twice the length of the corolla: fruit spinous. Pursh.

$O b$ s. This species is abundant throughout the forests in the rich lands of Kentucky. It is a tree of but ordinary stature, and for the most part of crooked growth, remarkable for the early period of its foliation, being the first of our trees to become green in the spring, and the earliest to cast its leaves in the fall.- The fruit is a large nut of a bright brown colour with a very remarkable hilum or eye, which has given the tree its common name: it is sometimes eaten by cattle, and often with fatal effects: Flowers about the 20th of April, and is then a very beautiful object: fruit ripens in September.

Syn. Pavia Lutea. Mich. fil.

Sorcies 2d. Esculus Flava.

Sweet Buckeye.

Sp. Ch. Leaves by 5s, pubescent underneath near the midrib, equally serrulate: corolla 4 -petalled, with the claws of the connivent petals longer than the calyx: fruit unarmed.

Obs. A much larger and straighter tree than the preceding, but less abundant than it, being in this locality confined to the alluvion bottoms of the Kentucky river. Unlike the former the wood of the sweet buckeye is susceptible of being applied to many useful purposes.- The flowers are unfolded towards the end of April and are succeeded by smooth capsules containing one or three large seeds.

Syn. Paria Ohioensis? Mich. fil. Sylva. Amer.

Stellaria. (See Genus 4.)

Species 9d. Stellaria Pubera.

Starivort.

Sp. Ch. Pubescent; leares sessile, ovate, ciliate; pedicels erect; petals longer than the calyx.

Obs. This species differs from the S. Media, before mentioned, in its less branching. and more erect habit. A single stem rises to the height of 6-8 inches, bearing a few comparatively large flowers. Rare; in woodlands. Flowers 20 th April.

(TO BE CONTINUED.) 


\section{ORIGINAL COMMENICATIONS.}

Ant. 1. A Valedictory Address delivered in the Chapel of Transylvania Lniversity, to the Medical Graduates at the Commencement on the 12th of March, 1828. By C'uart.ns Wilkixs Short, M. D. Dean of the Medical Faculty. - - _ _ Page II. An Essay on Milk-sickness. By Luxsforn Prty Yaxiez. M. M. D) of Murfreesborough, Tennessee.

III. Singular Cases. By Charles Calowkll, M. D. Professor of the Institutes of Mledicine and Clinical Practice, in Transylvania University.

IV. On the Chemoal changes that take place in the Blood, during Respiration, and the cause's of Animal Heat. By Jasws Bцтте, D. D. Professor of Chemistry in Transylvania University.

V. An Essay on Autumnal Diseases. By Joux Estex Cook E, M. D. Professor of the Theory and Practice of Medicine in Transylvania University.

VI. Florula Lexingtonicrsis, secundum florendi atatem digesta; or a descriptive Catalogue of the Phænogamous plants indigenous to this portion of Kentucky; arranged in the order of their flowering. By Crarurs Wilkins Short, M. D. Professor of Materia Medica and Medical Botany in Transylvania L'niversity. Fasciculus II. For April.

VII. On the Diseases which appeared in Henry County, Tennessee, in the summer and fall of 1827 and a brief account of their treatment, with remarks on the weather during the same. By Jorn Travis, M. D. of Henry County, Tennessee. - - - -

VIII. Case of Hysteria attended with some peculiarities. By J a mes Coveerst Cross, M. D. of Courtland, Ala.

IX. Case of Retroversion of the Lterus relieved by extract of Belladonna and Laudanum. By Dr. Joriv Mirls, of Winchester, Kentucky.

X. Cases of Lithotomy; with observations. By Levafond Pitrs Yandell, M. I). of Murfreesborough, Ten.

XI. Reriew of "Medical and Phỹsical Memoirs, (Neu S $\boldsymbol{c}_{\boldsymbol{c}}$ ries.) By Charles Caldwell, M. D. Prof. \&e. Printed at the request of the Class: Lexington, 1827." Comimunicated.

iographical notice of Dr. Frederick Ridgely, late of Lexington, Kentucky.

XIII. Meteorological Journal from February to May 1828. By Thoxas J. Matruews, A. M. Morrison Professor of Mathematics and Natural Philosophy in 'Transylvania University. 


\section{PROPOSED WESTERN PUBRICATIONS ON NATURAL HIS'TORY.}

We are much gratified to learn the intention of those able naturalists, Messrs. Maclure, Say and Lesucur, to publish at New Harmony, Indiana, the following works.

1. A Work on the Fishes of America, by $\mathbf{M r}$. Lesueur, with 4 coloured plates in each number; at 40 cents per number.

2. A Work on American Shells, by Mr. Say, with $\mathbf{1 0}$ coloured plates in each number, at $\$ 1.00$ per number.

3. Michaux's Sylva Americana; the proposals for the republication of which are thus announced by Mr. Maclure.

"Before I left Europe, I found that a London book-seller was on the point of purchasing the whole cdition of Mrchaux's Sylva Ameri caxa from that author, with all the copper-plates, which having only struck off about two or three hundred copies, are as good as new. I interfered, and bought the whole, because I thought it a stock-book that ought to be in all our libraries, as the only register of the greatest part of our folest trees; for after the cutting down of our woods, the most useful only will be left in preservation. And likewise, from the expense of publishing a new work, it is probable we shall never have another so perfect, of which the London book-seller, taking the advantage of his monopoly, would have made us pay dear; for, even when the work was in the hands of the author, the London price was 10 guineas per copy.

Being in possession of all the copper-plates, capable of printing thousands of copies-it is proposed to publish a new edition by subscription, in Nos. of five plates, coloured after nature, at one dollar per No. It is further intended, to add a number of trees, omitted by Michaux, to make the work more complete-and to begin the publication when one hundred subscribers shall be obtained.

Letters addressed to the editor of Michaux's Sylva Americana, NewHarmony, Indiana, (post paid) with the names of them that wish to become subscribers, will be attended to. $\Lambda$ gents will be approinted at the different places, when it shall be ascertained that the number of subscribers will warrant the publication.

The Sruva Americana, of Michanx, is not only an accurate botanical description of our forest trees, but contains considerable information on the nature and quality of their wood, localities, mode of cultivation, and uses they are put to, in the different States of the Union.

[New Harmony Disseminator.]

JUST PUBLISHED at Boston, Mass. and will be ready for subscribers in the Western country, in the course of a few weeks, MEMOIRS OF THE LIFE OF THE REv. HORACE HOLLEY, L. L. D. late President of Transylvania University. By Charles Caldwell, M. D. Professor of the Lnstitutes of Medicine and Clinical Practice in that Institution.

The success which these memoirs have met with, in the Atlantic States, has already rendered a second edition necessary to supply the demand. 




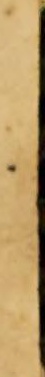




\section{TRANSYLVANIA UNIVERSTTY. \\ DTEDICAI DPS ABTRWTITIP.}

4

Trre Medical Lectures will commence, as usual, on the 1st Monday of Novemuer and end on the Ist Saturday of March.

BENJ AMIN W. DUDLEY, M. D. On Anatomy and Surgery.

CHARLES CAIDWELL, M. D. Institutes and Clinical Practice.

JOHN E. COOKE, M. D. Theory and Practice of Medicine.

WM. H. RICHARDSON, M. D. Obstetrics and Diseases of Women and Children.

CHARLES W. SHORT, M. D. Materia Micrica and Medical Botany.

JAMES BLYTHE, D. L. vielinistiy and Pharnacy.

Each Professor lectures daily, Sabbaths excepted. The Ticket ts the Anatomical and Surgical course is $\$ 20$; each of the others $\$ 15$. Matriculation with the use of the Library, $\$ 5$. The Tiratuation fee $\$ 20$.

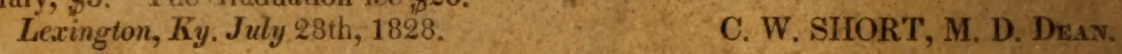

\section{LATELY PUBLUSHED,}

A TREATISE OF PATHOLOGY AND THERAPEUTICS by JoHN E. CookE, M. D. Professor of the Theory and Practice of Medieine in Transylvania University. In 2 Vols. 8vo, fine paper. Price Six Dollars.

This work may be had of Holdship \& Son, Pittsburg; E. H. Flint, Cincinnati; Robertson \& Elliott, and —_ Shepherd, Nashville, Tennessee; Wm. M. Gwin, M. D. Mansker's Creek near Nashville; T. Brandon, Esq. Huntsville, Alabama ; and the librarian at the Library of the Medical College, Lexington, Kentucky.

It will in the course of a month, be cleposited with Caroy, Lea $\mathrm{N}$ Carey, Philadelphia Plaskitt \& Co. or Armstrong, Baltimore; and Dr. S. M. Meek, Tuscalowsa, Alabama.

The Transylvania Journal of Medicine and the Associate Sciences, edited by Profes sors Cooke and Short assisted by the Medical Faculty of the School, is published quar: terly in numbers of 150 pages handsomely printed on good paper, The plan embraces matter chiefly original. The price is $\$ 300 \mathrm{in}$ advance, or $\$ 400$ at the end of the year. Those who wish to subscribe can have the numbers from the beginning.

\section{NOTICE TO CORRESPONDENTS.}

ALL communications for insertion, or on business of the Journal to be directed to "The editors of the Transylvania Journal of Medicine \&c. Lexington, Kentucky." 